FACTA UNIVERSITATIS

Series: Economics and Organization Vol. 18, No 1,2021 , pp. 1 - 16

https://doi.org/10.22190/FUEO201102002Z

Original Scientific Paper

\title{
TESTING HECKSCHER-OHLIN-VANEK THEOREM BY USING NORMALIZED TRADE BALANCE APPROACH
}

UDC 332.053

\section{Berislav Žmuk, Hrvoje Jošić}

University of Zagreb, Faculty of Economics and Business, Croatia

\begin{abstract}
The study described here introduces new approach for testing the HeckscherOhlin-Vanek (HOV) theorem based on the normalized trade balance concept. The intention was to include in the analysis all countries worldwide but due to the lack of data a certain number of countries had to be excluded. Overall 111 countries were observed according to region and income level for the year 2014. The HOV model was estimated using the sign test. It compared the expected sign of the normalized trade balance or net exports, according to the SITC 2 product classification, with the relative endowment of production factors intensively used in the production of a specific product. Production factors were divided into groups such as produced capital, labour force and natural resources further divided into forests, metals and minerals, oil, coal and gas, pastureland and cropland. Researchers in $R \& D$ per million people variable represented the impact of technological differences across countries. The results of the sign test have shown that the HOV theorem held in 55\% of cases. The percentage of matched signs was highest for the non-OECD high income countries (75\%) and lowest for the lower middle income and low income countries (below 50\%).
\end{abstract}

Key words: Heckscher-Ohlin-Vanek model, sign test, normalized trade balance approach, the World

JEL Classification: F1, F2

\section{INTRODUCTION}

Classical theories of international trade observed price determination and trade pattern only from the supply side. At that time labour was the only factor of production. Adam Smith's theory of absolute advantages determined the pattern of trade and specialization from

Received November 02, 2020 / Revised December 07, 2020 / Accepted December 09, 2020

Corresponding author: Berislav Žmuk

Faculty of Economics and Business, University of Zagreb, Trg J. F. Kennedyja 6, HR-10000 Zagreb, Croatia

E-mail: bzmuk@net.efzg.hr

ㄷ 2021 by University of Niš, Serbia | Creative Commons Licence: CC BY-NC-ND 
the different labour productivity in countries, while David Ricardo's theory of comparative advantages was based on different relative labour productivity. After the Industrial Revolution the capital was recognized as a factor of production as well. The neoclassical theory of international trade, established in 1920s and 1930s, was based on the HeckscherOhlin theory or also called the Factor Proportions Model (Heckscher, 1919 and Ohlin, 1924). In the Heckscher-Ohlin theory there are two factors of production, labour and capital. Comparative advantages are determined from the relative abundance of production factors. A country which is relatively abundant in a certain factor of production should export a commodity which intensively uses that factor of production. Leontief (1953) confronted the Heckscher-Ohlin theory with data for the United States using 1947 input-output tables. He came to the conclusion that the United States exported labour-intensive products and imported capital-intensive products, which was in contrast with the Heckscher-Ohlin theory, the result later named the Leontief paradox. The Heckscher-Ohlin theory has been subject of rigorous empirical investigation by many scientists but with little success. The results achieved on the sign test were often no better than flipping a coin. Vanek (1968) expanded the standard Heckscher-Ohlin model on a multi-country, multi-factor and multi-commodity framework and explained if a country's endowment in a certain factor of production exceeds that country's share in total World's GDP than that factor of production should be considered abundant. The so called Heckscher-Ohlin-Vanek (HOV) model or factor content model predicted that the content of relatively abundant factor embodied in export commodities should be larger than the content embodied in import commodities. The HOV theorem, however, did poorly in empirical research, primarily because of restrictive assumptions of the very theorem. According to Davis et al. (1997), the HOV theorem is a central theorem in international economics theory but empirically it is a flop. The empirical failure is owed extensively to examining the theory in its least realistic form.

The goal of this paper is to introduce a new approach for testing the Heckscher-OhlinVanek theorem based on the normalized trade balance concept and its application by using sign test. The novelty of our approach is implementation of normalized trade balance concept alongside with the use of sign test instead of calculating the factor content of trade. Therefore, the main advantage of this approach is simplification of the overall model by replacing the complex and complicated input-output matrix calculation process with the normalized trade balance. In addition, this simplified approach allows the larger sample of countries to be included in the analysis. There are five chapters in the paper. After the introduction, the second chapter provides literature review about empirical findings on the HOV model. Data and methodology are presented in chapter three. In the fourth chapter the results of the HOV model analysis are presented and elaborated while the last chapter offers concluding remarks.

\section{LITERATURE REVIEW}

In this chapter, literature review of empirical studies on the HOV model after Vanek's (1968) seminal paper are to be presented and elaborated. Bowen, Leamer and Sveikauskas (1987) examined the factor content of trade in a multi-factor and multi-country framework. The HOV theorem was tested using sign and rank test on twelve factors of production for 27 countries for the year 1967 by using the 1966 United States technology matrix. The number of correctly matched sign on the sign test was greater than $50 \%$ for eleven out of twelve factors 
and but greater than $70 \%$ for only four factors of production. The authors found that the main reasons why the HOV theorem has no strong support in data are disproportionate consumption, technological differences across countries and measurement errors. Kim (1991) used the factor content model to evaluate the trade patterns of Korea in trade with the United States and Japan using 1978 Korea's and the United States' total input requirements. He observed whether the factor abundance determines the sign of net exports. It was shown that the HOV theorem does not perform well in predicting trade patterns when differences in technological capabilities are ignored. Trefler (1995) investigated the features of data that led to the poor performance of the HOV theorem identifying pronounced patterns in the deviations from the HOV model. Important facts such as the case of missing trade and the endowments paradox have often gone unnoticed. Davis et al. (1997) used Japanese regional data to test the HOV model. The strict HOV theorem performed poorly. The authors made two modifications regarding the general model; they abandoned the notion of identical technologies across countries and focused on production and absorption instead of using trade data. Furthermore, when the assumption of universal factor price equalization was relaxed, the HOV model performed remarkably well. Maskus and Webster (1999) developed a version of the HOV theorem with parametric technological differences. The econometric model on factor contents of trade data, output and consumption for the United States and the United Kingdom allowed for factorspecific and industry-specific productivity differences. Davis and Weinsten (2001) emphasized the importance of intermediates, aggregation bias and differences in patterns of absorption. Choi (2004) relaxed the assumption of ideal factor price equalization deriving a modified HOV theorem to predict the factor content of trade. The modified HOV theorem used inputoutput coefficients of the source country for each traded good which resulted in approval of theorem validity. Romalis (2004) derived and examined the factor proportions model in commodity markets. He made modifications in the standard Heckscher-Ohlin model by introducing transport costs and monopolistic competition. There was support in data for the Rybczynski effect for fast-growing economies. Chakrabarti (2005) demonstrated the importance of accounting for the absorption of inputs in a factor augmenting model of international productivity differences. The absence of such accounting can lead to biases in calculation of productivity parameters and could raise concerns about the decision about the HOV theorem acceptance or rejection. Requena et al. (2005) studied the HOV model empirically using Spanish regional data. After relaxing the strict assumptions of the HOV theorem such as factor price equalization, identical homothetic preferences and Hicks neutral technological differences, the model performed poorly.

Nishioka (2005) explored the international trade within the HOV model for the developed OECD countries. The knowledge factor was introduced into the HOV framework. It played an important role in determining comparative advantages for technologically advanced OECD countries. The strict HOV model with the inclusion of knowledge capital held on its own. Maskus and Nishioka (2006) estimated factor productivities from individual technology data for 15 OECD countries. The HOV theorem showed ability to explain North-South factor trade depending on factor abundance and productivity gaps. Factor-augmenting productivity differences were found as appropriate modification of the HOV theorem. Artal-Tur et al. (2008) built an assemble dataset for 17 Spanish regions for the years 1995, 2001 and 2004 by employing regional specific input-output tables. The inclusion of intermediate inputs in the computation of technology matrix slightly improved the number of correct matches on the sign test. Lu, Milner and Yu (2009) applied factor content tests using data for 58 countries and six factors of production. The results in general showed weak support for the HOV model with minor improvements achieved after adjusting for technology differences across countries. 
Srivastava (2012) tackled the HOV theorem with the help of the excess supply approach by examining trade performances of ten manufacturing industries in 46 countries for the year 2009. The major source of comparative advantages were capital stock and secondary and higher educated labour. The HOV theorem proved to be valid in more than $60 \%$ of cases. Srivastava and Mathur (2014) performed partial and complete tests to investigate the validity of the HOV theorem using India's industry level data from 1989 to 2008 and five factors of production (primary educated labour force, secondary and tertiary level of educated labour force, capital and arable land). Measured signs were correct in more than $50 \%$ of cases. Zimring (2015) observed a large and rapid expansion of labour force in West Bank due to near-elimination of commuting into Israel. Production shifted to more labour-intensive industries (the Rybczynski effect). Allowing for district specific deviations the changes in production were consistent with the HOV model of trade. Jošić (2016) tested the factor proportions model in the case of Croatia based on the bilateral merchandise trade data between Croatia and the countries of the European Union and worldwide using the sign test. The results of the sign test have shown that Croatia does not use its comparative advantages effectively, leading to the rejection of the factor proportions model. Wu et al. (2017) investigated the greenhouse gas emissions intensities in Canadian agriculture and processed food industry. Natural resources were found to be the determining factor of Canadian agricultural structure whereby Canadian exports were more capital-intensive than imports.

\section{DATA AND METHODOLOGY}

The intention was to include in the analysis all countries worldwide. Unfortunately, due to the lack of data a certain number of countries had to be excluded from the analysis. Despite that, 111 countries were observed overall. Table 1 reveals that all parts of the World are well represented regionally. Table 2 shows the distribution of observed countries according to their income. The full list of observed countries is displayed in Table 7.

Table 1 Distribution of observed countries according to their geographic region

\begin{tabular}{lc}
\hline Region & Number of countries \\
\hline East Asia \& Pacific & 13 \\
Europe \& Central Asia & 37 \\
Latin America \& Caribbean & 16 \\
Middle East \& North Africa & 12 \\
North America & 2 \\
South Asia & 4 \\
Sub-Saharan Africa & 27 \\
Total & 111 \\
\hline hors according to World Bank (2018, 2019a-d) and Trade Map (2019)
\end{tabular}

Source: authors according to World Bank (2018, 2019a-d) and Trade Map (2019).

Table 2 Distribution of observed countries according to their income

\begin{tabular}{lc}
\hline Income level & Number of countries \\
\hline Low income & 17 \\
Lower middle income & 27 \\
Upper middle income & 24 \\
High income: non-OECD & 14 \\
High income: OECD & 29 \\
Total & 111 \\
\hline hors according to World Bank (2018, 2019a-d) and Trade Map (2019).
\end{tabular}


In order to perform the factor endowment analysis, the data have been collected for 10 different variables representing factors of production, GDP and technology differences. The starting point for the variable selection were the previous findings in this field of research with papers presented in the literature review. The final decision upon the list of variables which were included in the analysis, was made based on data availability. World Bank (2018, 2019a-d) and Trade Map (2019) databases were used as data sources. The complete list of observed variables is displayed in Table 3.

Table 3 List of observed variables

\begin{tabular}{lcl}
\hline Variable group & Variable code & Variable \\
\hline Income & GDP & Gross domestic product (GDP) (in USD) \\
\hline \multirow{2}{*}{ Production factors } & PCAP & Produced capital (in USD) \\
& LABF & Labour force (number of persons) \\
\hline \multirow{3}{*}{ Natural resources } & FOR & Forests (in USD) \\
& MMIN & Metals and minerals (in USD) \\
& OCNG & Oil, coal and natural gas (in USD) \\
& PAST & Pastureland (in USD) \\
\hline Technology & FROP & Cropland (in USD) \\
\hline
\end{tabular}

Source: authors according to World Bank (2018, 2019a-d) and Trade Map (2019).

Furthermore, the data availability determined the observed period as well. It has been decided that data which are available for the most recent period will be collected. According to the observed databases it turned out that the data for the year 2014 are the most recent one for the most of observed variables. Unfortunately, the R\&D variable had missing data for 46 countries $(41.44 \%)$. In these cases, the data for the period closest to the year 2014 were used as an approximation for 2014 data. The fact that the missing values were imputed by using data from different periods should be taken as a limitation of the research. Therefore, the results where $R \& D$ variable was included in the analysis should be observed and discussed with special attention. According to Erlat and Erlat (2003) products can be grouped into five groups with a different product factor intensity level. The goods have been classified into five product groups according to their product intensity. Those are raw material intensive goods (RMIG), labour-intensive goods (LIG), capital-intensive goods (CIG), easy-to-imitate research-intensive goods (EIRIG) and difficult-to-imitate researchintensive goods (DIRIG). The HOV model is defined as follows (Feenstra, 2003):

$$
F_{i}=V_{i}-s_{i} V_{w}
$$

where $F_{i}$ is the factor content of trade of country $i, V_{i}$ is the factor abundance of the country $i, s_{i}$ is the share of $i$-th country's GDP in the World GDP and $V_{w}$ is the World factor abundance. In the traditional HOV model the signs on the left and right side of the Equation 1 are compared. Standard sign tests of the HOV theorem go roughly as follows: (1) calculate the imports and exports of a country in terms of factors embodied in the goods that are traded, (2) compare the country's share of World's GDP to a country's share of each factor of endowment in the total World's endowment of that factor and (3) a country should be a net exporter of products that intensively uses abundant factor of production. 
This paper implements new approach to explore the validity of the Heckscher-Ohlin-Vanek theorem by using normalized trade balance concept on the left side of the Equation 1. Therefore, instead of calculating net factor content of trade from input-output tables, the normalized trade balance was calculated. The normalized trade balance is calculated using the following equation:

$$
T B_{i j}=\frac{E_{i j}-I_{i j}}{E_{i j}+I_{i j}}
$$

where $T B_{i j}$ is trade balance of country $i$ for the product group $j, E_{i j}$ is export of country $i$ for product group $j$ and $I_{i j}$ is the import of country $i$ for the product group $j$. According to the Equation 2, if the export of products in a country $i$ is larger than the import of the same product groups, the resulting sign is positive and vice versa. The Equation 2 assumes identical technology and factor content of imports and exports, which can be observed as a disadvantage of new the approach. The normalized trade balance alone, however, does not measure the factor content of trade. It has been used as a concept in the literature for decades as an alternative measure for the revealed comparative advantage. Therefore, in the paper the sign test is conducted by comparing the expected sign of the net exports of SITC 2 product classification with the relative endowment of production factors intensively used in the production of a specific product, as given here:

$$
\operatorname{Sign}(T B)=\operatorname{Sign}\left(V_{i}^{k}-s_{i} V_{w}^{k}\right)
$$

This paper takes a different approach, testing the HOV theorem good-by-good. That is, instead of testing whether country's total trade in a factor is as we would expect from the country's factor abundance, it tests, for each good the country trades, whether it is traded (on net) in the right direction. For example, if a country is labour abundant, it tests whether each good that is produced with the labour intensive technology is (on net) exported. The whole analysis procedure can be briefly described as follows. Firstly, the standardized trade balances for each of 96 product groups (there are no groups of products with codes 00,77 and 98 whereas the product group 99 includes everything that was not classified before and because of that it is omitted from the analysis) of all 111 countries are calculated separately. Afterwards, the values of variables for each observed country are compared to the World value and the corresponding share (proportion) is calculated. Due to the specific characteristics of the $R \& D$ variable, for this variable the countries values are compared to the World average value. The resulting shares or proportions are then compared to the GDP share of the observed country in the overall World GDP value. If the calculated share is higher than the GDP share, it is assumed that the observed country is abundant in that factor of production. Consequently, the conclusion is that the country should export product which intensively uses the abundant factor of production and in that case the positive sign will be achieved on the sign test. Finally, two estimated signs are compared and it is checked whether they match or not. It is assumed that the sign test will result in a match in at least $50 \%$ of cases. 


\section{RESULTS AND DISCUSSION}

The sign test will be conducted by using the total of 10 variables observed in the data and methodology section. In order to get the insight about the distributions of the observed variables in Table 4, the basic descriptive statistics of results is provided.

Table 4 Descriptive statistics results of the observed variables, $n=111$ selected countries, data for 2014

\begin{tabular}{llrrrrrrrrr}
\hline \multirow{2}{*}{ Variable } & \multirow{2}{*}{ Unit } & \multicolumn{10}{c}{ Statistics } \\
\cline { 3 - 10 } & & \multicolumn{1}{c}{ Average St. Dev. Coeff. var. } & Min & 1st quart. & Median & 3rd quart. & Max \\
\hline GDP & bil. USD & 669 & 2,038 & 304 & 1 & 20 & 66 & 405 & 17,428 \\
PCAP & bil. USD & 2,688 & 8,164 & 304 & 3 & 66 & 236 & 1,425 & 68,943 \\
LABF & mill. per. & 27 & 89 & 332 & 0 & 2 & 6 & 19 & 787 \\
MMIN & bil. USD & 87 & 315 & 362 & 0 & 0 & 3 & 21 & 2,101 \\
FOR & bil. USD & 21 & 52 & 251 & 0 & 1 & 5 & 16 & 353 \\
OCNG & bil. USD & 275 & 765 & 279 & 0 & 0 & 4 & 80 & 4,952 \\
PAST & bil. USD & 119 & 350 & 295 & 0 & 10 & 29 & 75 & 2,848 \\
CROP & bil. USD & 225 & 963 & 427 & 0 & 10 & 43 & 123 & 9,676 \\
FISH & mill. MT & 2 & 8 & 479 & 0 & 0 & 0 & 1 & 76 \\
R\&D & no. per mill. & 1,566 & 2,024 & 129 & 7 & 70 & 565 & 2,640 & 7,311 \\
\hline
\end{tabular}

Source: authors' calculation.

According to the descriptive statistics results from the Table 4 it can be easily concluded that there are huge differences between 111 observed countries for each of the selected variables. The lowest variation in data, according to the coefficient of variation, seems to be for the R\&D variable (129\%) whereas the largest is for the FISH variable (479\%). The comparison of differences between the minimum and the maximum values shows that data ranges are very wide. If the values of quartiles are observed, it can be concluded that all variables are highly positively skewed.

The main descriptive statistics results of calculated shares for the observed countries in the whole World value are shown in Table 5. As expected, according to the results from Table 4, huge differences in shares (proportions) are present here as well.

Table 5 Descriptive statistics of calculated shares for the observed countries in the whole World value, $n=111$ selected countries, data for 2014

\begin{tabular}{lrrrrrrrrrr}
\hline \multirow{2}{*}{ Statistics } & \multicolumn{10}{c}{ Variable } \\
\cline { 2 - 11 } & \multicolumn{1}{c}{ GDP } & PCAP & LABF & MMIN & FOR & OCNG & PAST & CROP & FISH & R\&D \\
\hline Average & 0.0085 & 0.0089 & 0.0081 & 0.0086 & 0.0087 & 0.0070 & 0.0085 & 0.0087 & 0.0081 & 1.0628 \\
St.Dev. & 0.0258 & 0.0269 & 0.0268 & 0.0310 & 0.0218 & 0.0196 & 0.0250 & 0.0372 & 0.0390 & 1.3742 \\
Coeff.Var. & 304 & 304 & 332 & 362 & 251 & 279 & 295 & 427 & 479 & 129 \\
Min & 0.0000 & 0.0000 & 0.0001 & 0.0000 & 0.0000 & 0.0000 & 0.0000 & 0.0000 & 0.0000 & 0.0049 \\
1st quar. & 0.0002 & 0.0002 & 0.0007 & 0.0000 & 0.0004 & 0.0000 & 0.0007 & 0.0004 & 0.0001 & 0.0476 \\
Median & 0.0008 & 0.0008 & 0.0019 & 0.0003 & 0.0019 & 0.0001 & 0.0021 & 0.0016 & 0.0009 & 0.3832 \\
3rd quar. & 0.0051 & 0.0047 & 0.0058 & 0.0021 & 0.0067 & 0.0020 & 0.0054 & 0.0048 & 0.0032 & 1.7920 \\
Max & 0.2202 & 0.2271 & 0.2360 & 0.2069 & 0.1471 & 0.1267 & 0.2036 & 0.3736 & 0.3934 & 4.9628 \\
\hline
\end{tabular}




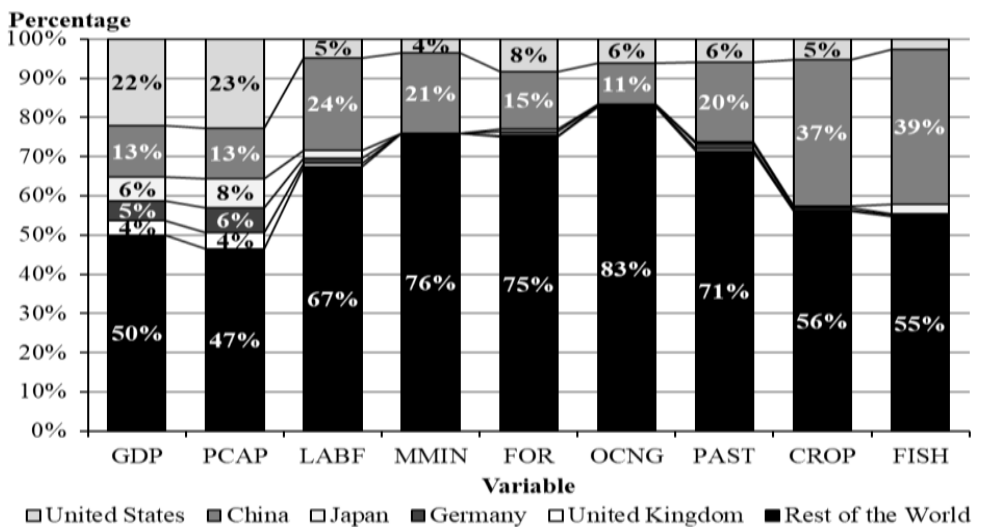

Fig. 1 Factor endowment shares, top five countries according to the GDP share in the World value and the rest of the World, data from 2014

In Figure 1 the top five countries according to the share of GDP value in the total World GDP value are emphasized. According to the Figure 1, those five countries (the United States of America, China, Japan, Germany and the United Kingdom) together encompass the half of the World's total GDP. What's more intriguing, they together dispose with more than half of the World's total produced capital. In other observed variables, the main contributor to the share of those five countries in the total World's values is China meaning that China is abundant in these factors of production. Whereas in Figure 1 five countries with the largest GDP share in the World value were pointed out, in Table 6 countries with the lowest shares of each variable in the whole World value were displayed.

Table 6 The last five observed countries according to observed variables values compared to the World level, data for 2014

\begin{tabular}{|c|c|c|c|c|c|c|}
\hline Variable & Statistics & Rank 111 & Rank 110 & Rank 109 & Rank 108 & Rank 107 \\
\hline \multirow{2}{*}{ GDP } & Country & Gambia & Swaziland & Togo & Malawi & Moldova \\
\hline & Value & $1.5911 \mathrm{E}-05$ & $5.5317 \mathrm{E}-05$ & $5.7738 \mathrm{E}-05$ & 7.6427E-05 & $1.0089 \mathrm{E}-04$ \\
\hline \multirow{2}{*}{ PCAP } & Country & Gambia & Togo & Malawi & Rwanda & Madagascar \\
\hline & Value & $9.8129 \mathrm{E}-06$ & $4.6023 \mathrm{E}-05$ & $5.1648 \mathrm{E}-05$ & $5.7452 \mathrm{E}-05$ & $7.1365 \mathrm{E}-05$ \\
\hline \multirow{2}{*}{ LABF } & Country & Iceland & Malta & Luxembourg & Swaziland & Mauritius \\
\hline & Value & $5.9652 \mathrm{E}-05$ & $5.9865 \mathrm{E}-05$ & $8.2163 \mathrm{E}-05$ & $1.2904 \mathrm{E}-04$ & $1.7930 \mathrm{E}-04$ \\
\hline \multirow[t]{2}{*}{ MMIN } & Country & \multicolumn{5}{|c|}{$\begin{array}{c}\text { Bahrain, Belgium, Cambodia, Denmark, El Salvador, Estonia, Gambia, Iceland, Italy, Kuwait, Latvia, } \\
\text { Lithuania, Malta, Mauritius, Moldova, Nepal, Netherlands, Paraguay, Qatar, Singapore, Slovenia, Swaziland, } \\
\text { United Arab Emirates, West Bank and Gaza }\end{array}$} \\
\hline & Value & \multirow{3}{*}{\multicolumn{2}{|c|}{$\begin{array}{c}\text { Malta, West Bank and Gaza } \\
0\end{array}$}} & 0 & & \\
\hline \multirow{2}{*}{ FOR } & Country & & & Bahrain & Iceland & Oman \\
\hline & Value & & & $2.1372 \mathrm{E}-07$ & 5.3979E-07 & $8.9456 \mathrm{E}-07$ \\
\hline \multirow[t]{2}{*}{ OCNG } & Country & \multirow{2}{*}{\multicolumn{5}{|c|}{$\begin{array}{l}\text { Belgium, Burkina Faso, Cambodia, Costa Rica, El Salvador, Finland, Gambia, Honduras, Iceland, Kenya, } \\
\text { Latvia, Luxembourg, Madagascar, Mali, Malta, Mauritius, Namibia, Nicaragua, Panama, Paraguay, Portugal, } \\
\text { Rwanda, Singapore, Sri Lanka, Sweden, Switzerland, Togo, Uganda, Uruguay, West Bank and Gaza }\end{array}$}} \\
\hline & Value & & & & & \\
\hline \multirow{2}{*}{ PAST } & Country & Singapore & Malta & Bahrain & Mauritius & Qatar \\
\hline & Value & $1.4069 \mathrm{E}-07$ & 1.4813E-05 & 3.4674E-05 & $3.5316 \mathrm{E}-05$ & $6.5091 \mathrm{E}-05$ \\
\hline \multirow{2}{*}{ CROP } & Country & Iceland & Singapore & Bahrain & Malta & Luxembourg \\
\hline & Value & $2.4472 \mathrm{E}-06$ & $6.9917 \mathrm{E}-06$ & $1.0849 \mathrm{E}-05$ & $1.7096 \mathrm{E}-05$ & $1.7712 \mathrm{E}-05$ \\
\hline \multirow{2}{*}{ FISH } & Country & Luxembourg & Swaziland & Botswana & Macedonia, FYR & Jordan \\
\hline & Value & 0 & $8.5295 \mathrm{E}-07$ & $6.0379 \mathrm{E}-06$ & 7.7334E-06 & $9.0878 \mathrm{E}-06$ \\
\hline \multirow{2}{*}{$\mathrm{R} \& \mathrm{D}$} & Country & Congo, Dem. Rep. & Niger & Rwanda & Lao PDR & Tanzania \\
\hline & Value & $4.9069 \mathrm{E}-03$ & $5.0343 \mathrm{E}-03$ & $8.3818 \mathrm{E}-03$ & $1.0743 \mathrm{E}-02$ & $1.2448 \mathrm{E}-02$ \\
\hline
\end{tabular}

Source: authors' calculation. 
Table 7 Results of the sign tests according to the observed countries, data for 2014

\begin{tabular}{|c|c|c|c|c|c|c|c|}
\hline \multirow{2}{*}{ Country } & \multicolumn{2}{|c|}{ Sign matching } & \multirow{2}{*}{$\begin{array}{c}\text { Share of } \\
\text { matched signs }\end{array}$} & \multirow{2}{*}{ Country } & \multicolumn{2}{|c|}{ Sign matching } & \multirow{2}{*}{$\begin{array}{c}\text { Share of } \\
\text { matched signs }\end{array}$} \\
\hline & Yes & No & & & Yes & No & \\
\hline Albania & 27 & 68 & $28 \%$ & Madagascar & 52 & 44 & $54 \%$ \\
\hline Argentina & 75 & 21 & $78 \%$ & Malawi & 47 & 49 & $49 \%$ \\
\hline Australia & 57 & 39 & $59 \%$ & Malaysia & 47 & 49 & $49 \%$ \\
\hline Austria & 58 & 38 & $60 \%$ & Mali & 39 & 57 & $41 \%$ \\
\hline Bahrain & 84 & 12 & $88 \%$ & Malta & 71 & 25 & $74 \%$ \\
\hline Belgium & 47 & 49 & $49 \%$ & Mauritius & 59 & 37 & $61 \%$ \\
\hline Bolivia & 49 & 47 & $51 \%$ & Mexico & 60 & 36 & $63 \%$ \\
\hline Bosnia and Herzegovina & 37 & 59 & $39 \%$ & Moldova & 41 & 54 & $43 \%$ \\
\hline Botswana & 50 & 46 & $52 \%$ & Morocco & 35 & 61 & $36 \%$ \\
\hline Brazil & 65 & 31 & $68 \%$ & Mozambique & 40 & 56 & $42 \%$ \\
\hline Bulgaria & 35 & 61 & $36 \%$ & Namibia & 54 & 42 & $56 \%$ \\
\hline Burkina Faso & 46 & 48 & $49 \%$ & Nepal & 48 & 48 & $50 \%$ \\
\hline Cambodia & 50 & 45 & $53 \%$ & Netherlands & 62 & 34 & $65 \%$ \\
\hline Canada & 54 & 42 & $56 \%$ & Nicaragua & 39 & 57 & $41 \%$ \\
\hline Chad & 42 & 53 & $44 \%$ & Niger & 23 & 70 & $25 \%$ \\
\hline Chile & 74 & 22 & $77 \%$ & Nigeria & 36 & 60 & $38 \%$ \\
\hline China & 61 & 35 & $64 \%$ & Norway & 65 & 31 & $68 \%$ \\
\hline Colombia & 48 & 48 & $50 \%$ & Oman & 87 & 8 & $92 \%$ \\
\hline Congo, Dem. Rep. & 30 & 66 & $31 \%$ & Pakistan & 57 & 39 & $59 \%$ \\
\hline Congo, Rep. & 23 & 72 & $24 \%$ & Panama & 79 & 17 & $82 \%$ \\
\hline Costa Rica & 49 & 47 & $51 \%$ & Papua New Guinea & 43 & 53 & $45 \%$ \\
\hline Cote d'Ivoire & 48 & 48 & $50 \%$ & Paraguay & 49 & 47 & $51 \%$ \\
\hline Croatia & 63 & 33 & $66 \%$ & Philippines & 52 & 44 & $54 \%$ \\
\hline Denmark & 49 & 47 & $51 \%$ & Poland & 47 & 49 & $49 \%$ \\
\hline Ecuador & 44 & 52 & $46 \%$ & Portugal & 44 & 52 & $46 \%$ \\
\hline Egypt, Arab rep. & 49 & 47 & $51 \%$ & Qatar & 88 & 8 & $92 \%$ \\
\hline El Salvador & 45 & 51 & $47 \%$ & Romania & 34 & 59 & $37 \%$ \\
\hline Estonia & 57 & 39 & $59 \%$ & Russian Federation & 63 & 33 & $66 \%$ \\
\hline Ethiopia & 48 & 47 & $51 \%$ & Rwanda & 43 & 53 & $45 \%$ \\
\hline Finland & 64 & 32 & $67 \%$ & Senegal & 45 & 51 & $47 \%$ \\
\hline France & 59 & 37 & $61 \%$ & Singapore & 67 & 29 & $70 \%$ \\
\hline Gambia, The & 41 & 53 & $44 \%$ & Slovak Republic & 59 & 37 & $61 \%$ \\
\hline Georgia & 35 & 61 & $36 \%$ & Slovenia & 58 & 38 & $60 \%$ \\
\hline Germany & 51 & 45 & $53 \%$ & South Africa & 36 & 59 & $38 \%$ \\
\hline Ghana & 41 & 55 & $43 \%$ & Spain & 45 & 51 & $47 \%$ \\
\hline Greece & 54 & 42 & $56 \%$ & Sri Lanka & 60 & 36 & $63 \%$ \\
\hline Guatemala & 43 & 53 & $45 \%$ & Swaziland & 35 & 61 & $36 \%$ \\
\hline Honduras & 39 & 57 & $41 \%$ & Sweden & 63 & 33 & $66 \%$ \\
\hline Hungary & 45 & 51 & $47 \%$ & Switzerland & 63 & 33 & $66 \%$ \\
\hline Iceland & 57 & 39 & $59 \%$ & Tanzania & 50 & 46 & $52 \%$ \\
\hline India & 62 & 34 & $65 \%$ & Thailand & 63 & 33 & $66 \%$ \\
\hline Indonesia & 59 & 37 & $61 \%$ & Togo & 41 & 51 & $45 \%$ \\
\hline Iraq & 87 & 3 & $97 \%$ & Tunisia & 43 & 53 & $45 \%$ \\
\hline Ireland & 66 & 30 & $69 \%$ & Turkey & 64 & 32 & $67 \%$ \\
\hline Italy & 44 & 52 & $46 \%$ & Uganda & 50 & 46 & $52 \%$ \\
\hline Japan & 68 & 28 & $71 \%$ & Ukraine & 39 & 56 & $41 \%$ \\
\hline Jordan & 54 & 41 & $57 \%$ & United Arab Emirates & 70 & 26 & $73 \%$ \\
\hline Kazakhstan & 72 & 23 & $76 \%$ & United Kingdom & 68 & 28 & $71 \%$ \\
\hline Kenya & 50 & 46 & $52 \%$ & United States & 59 & 37 & $61 \%$ \\
\hline Korea, Rep. & 64 & 32 & $67 \%$ & Uruguay & 63 & 33 & $66 \%$ \\
\hline Kuwait & 89 & 7 & $93 \%$ & Venezuela, RB & 75 & 21 & $78 \%$ \\
\hline Lao PDR & 45 & 51 & $47 \%$ & Vietnam & 53 & 42 & $56 \%$ \\
\hline Latvia & 54 & 42 & $56 \%$ & West Bank and Gaza & 30 & 62 & $33 \%$ \\
\hline Lithuania & 58 & 38 & $60 \%$ & Zambia & 32 & 64 & $33 \%$ \\
\hline Luxembourg & 61 & 35 & $64 \%$ & Zimbabwe & 43 & 53 & $45 \%$ \\
\hline Macedonia, FYR & 41 & 54 & $43 \%$ & & & & \\
\hline
\end{tabular}

The calculated shares for the observed countries in the whole World value are paired with a certain product groups and are compared with the GDP share. In the case when the calculated share for a certain product group in a country is larger than the share of GDP in 
total World's GDP value, a positive sign is attached to that product group. Namely, in that case, it is expected that the country should have a positive net exports in that product. The Equation 2 is used to calculate the normalized trade balances for each product groups and for each country. If the normalized trade balance results in a positive score, a positive sign should also be obtained for country's factor endowment. The sign test is conducted by checking whether the two estimated signs match or not. The assumption is that the factor endowment signs and normalized trade balance signs would match in at least $50 \%$ of cases.

In Table 7 the results of the sign tests for each of the observed countries are shown. Overall sign matching rate turned out to be 55\% (5,845 matched signs and 4,774 unmatched signs) which is similar to what has been found out within the standard signs test in previous studies leading to the conclusion that HOV theorem does not offer a very good description of reality. The countries with the highest sign matching rates, which are above $90 \%$, are Iraq (97\%), Kuwait (93\%), Qatar (92\%) and Oman (92\%). On the other hand, countries with the lowest sign matching rates, which are below $30 \%$, are the Republic of the Congo (24\%), Niger (25\%) and Albania (28\%).

Table 8 Results of the sign tests according to the groups of products, data for 2014

\begin{tabular}{|c|c|c|c|c|}
\hline \multirow{2}{*}{ Code } & \multirow{2}{*}{ Product } & \multicolumn{2}{|c|}{ Sign matching } & \multirow{2}{*}{$\begin{array}{c}\text { Share of } \\
\text { matched signs }\end{array}$} \\
\hline & & Yes & No & \\
\hline 01 & Live animals & 44 & 67 & $40 \%$ \\
\hline 02 & Meat and edible meat offal & 52 & 59 & $47 \%$ \\
\hline 03 & Fish and crustaceans, molluscs and other aquatic invertebrates & 75 & 36 & $68 \%$ \\
\hline 04 & Dairy produce; birds' eggs; natural honey; edible products of animal origin & 45 & 66 & $41 \%$ \\
\hline 05 & Products of animal origin, not elsewhere specified or included & 55 & 56 & $50 \%$ \\
\hline 06 & Live trees and other plants; bulbs, roots and the like; cut flowers etc. & 65 & 46 & $59 \%$ \\
\hline 07 & Edible vegetables and certain roots and tubers & 68 & 43 & $61 \%$ \\
\hline 08 & Edible fruit and nuts; peel of citrus fruit or melons & 77 & 34 & $69 \%$ \\
\hline 09 & Coffee, tea, maté and spices & 77 & 34 & $69 \%$ \\
\hline 10 & Cereals & 49 & 62 & $44 \%$ \\
\hline 11 & Products of the milling industry; malt; starches; inulin; wheat gluten & 48 & 63 & $43 \%$ \\
\hline 12 & Oil seeds and oleaginous fruits; miscellaneous grains, seeds and fruit; etc. & 67 & 44 & $60 \%$ \\
\hline 13 & Lac; gums, resins and other vegetable saps and extracts & 54 & 57 & $49 \%$ \\
\hline 14 & Vegetable plaiting materials; vegetable products not elsewhere spec. etc. & 78 & 31 & $72 \%$ \\
\hline 15 & Animal or vegetable fats and oils and their cleavage products; etc. & 64 & 47 & $58 \%$ \\
\hline 16 & Preparations of meat, of fish or of crustaceans, molluscs etc. & 73 & 38 & $66 \%$ \\
\hline 17 & Sugars and sugar confectionery & 60 & 51 & $54 \%$ \\
\hline 18 & Cocoa and cocoa preparations & 58 & 53 & $52 \%$ \\
\hline 19 & Preparations of cereals, flour, starch or milk; pastry cooks' products & 46 & 65 & $41 \%$ \\
\hline 20 & Preparations of vegetables, fruit, nuts or other parts of plants & 64 & 47 & $58 \%$ \\
\hline 21 & Miscellaneous edible preparations & 43 & 68 & $39 \%$ \\
\hline 22 & Beverages, spirits and vinegar & 65 & 46 & $59 \%$ \\
\hline 23 & Residues and waste from the food industries; prepared animal fodder & 56 & 55 & $50 \%$ \\
\hline 24 & Tobacco and manufactured tobacco substitutes & 53 & 58 & $48 \%$ \\
\hline 25 & Salt; sulphur; earths and stone; plastering materials, lime and cement & 64 & 47 & $58 \%$ \\
\hline 26 & Ores, slag and ash & 81 & 30 & $73 \%$ \\
\hline 27 & Mineral fuels, mineral oils and products of their distillation; etc. & 95 & 16 & $86 \%$ \\
\hline 28 & Inorganic chemicals; organic or inorganic compounds etc. & 68 & 43 & $61 \%$ \\
\hline 29 & Organic chemicals & 76 & 35 & $68 \%$ \\
\hline 30 & Pharmaceutical products & 85 & 26 & $77 \%$ \\
\hline 31 & Fertilisers & 64 & 47 & $58 \%$ \\
\hline 32 & Tanning or dyeing extracts; tannins and their derivatives; dyes, etc. & 78 & 33 & $70 \%$ \\
\hline 33 & Essential oils and resinoids; perfumery, cosmetic or toilet preparations & 65 & 46 & $59 \%$ \\
\hline 34 & Soap, organic surface-active agents, washing preparations, etc. & 70 & 41 & $63 \%$ \\
\hline
\end{tabular}




\begin{tabular}{|c|c|c|c|c|}
\hline \multirow{2}{*}{ Code } & \multirow{2}{*}{ Product } & \multicolumn{2}{|c|}{ Sign matching } & \multirow{2}{*}{$\begin{array}{c}\text { Share of } \\
\text { matched signs }\end{array}$} \\
\hline & & Yes & No & \\
\hline 35 & Albuminoidal substances; modified starches; glues; enzymes & 85 & 26 & $77 \%$ \\
\hline 36 & Explosives; pyrotechnic products; matches; pyrophoric alloys; etc. & 74 & 37 & $67 \%$ \\
\hline 37 & Photographic or cinematographic goods & 81 & 30 & $73 \%$ \\
\hline 38 & Miscellaneous chemical products & 82 & 29 & $74 \%$ \\
\hline 39 & Plastics and articles thereof & 85 & 26 & $77 \%$ \\
\hline 40 & Rubber and articles thereof & 35 & 76 & $32 \%$ \\
\hline 41 & Raw hides and skins (other than fur skins) and leather & 62 & 49 & $56 \%$ \\
\hline 42 & Articles of leather; saddlery and harness; travel goods, handbags etc. & 55 & 56 & $50 \%$ \\
\hline 43 & Fur skins and artificial fur; manufactures thereof & 45 & 60 & $43 \%$ \\
\hline 44 & Wood and articles of wood; wood charcoal & 78 & 33 & $70 \%$ \\
\hline 45 & Cork and articles of cork & 49 & 62 & $44 \%$ \\
\hline 46 & Manufactures of straw, of esparto or of other plaiting materials; etc. & 70 & 41 & $63 \%$ \\
\hline 47 & Pulp of wood or of other fibrous cellulosic material; recovered etc. & 60 & 50 & $55 \%$ \\
\hline 48 & Paper and paperboard; articles of paper pulp, of paper or of paperboard & 39 & 72 & $35 \%$ \\
\hline 49 & Printed books, newspapers, pictures and other products of the printing etc. & 37 & 74 & $33 \%$ \\
\hline 50 & Silk & 51 & 58 & $47 \%$ \\
\hline 51 & Wool, fine or coarse animal hair; horsehair yarn and woven fabric & 38 & 73 & $34 \%$ \\
\hline 52 & Cotton & 55 & 56 & $50 \%$ \\
\hline 53 & Other vegetable textile fibres; paper yarn and woven fabrics of paper yarn & 54 & 57 & $49 \%$ \\
\hline 54 & Man-made filaments; strip and the like of man-made textile materials & 44 & 67 & $40 \%$ \\
\hline 55 & Man-made staple fibres & 46 & 65 & $41 \%$ \\
\hline 56 & Wadding, felt and nonwovens; special yarns; twine, cordage, ropes etc. & 43 & 68 & $39 \%$ \\
\hline 57 & Carpets and other textile floor coverings & 50 & 61 & $45 \%$ \\
\hline 58 & Special woven fabrics; tufted textile fabrics; lace; tapestries; etc. & 42 & 69 & $38 \%$ \\
\hline 59 & Impregnated, coated, covered or laminated textile fabrics; etc. & 36 & 75 & $32 \%$ \\
\hline 60 & Knitted or crocheted fabrics & 36 & 74 & $33 \%$ \\
\hline 61 & Articles of apparel and clothing accessories, knitted or crocheted & 71 & 40 & $64 \%$ \\
\hline 62 & Articles of apparel and clothing accessories, not knitted or crocheted & 70 & 41 & $63 \%$ \\
\hline 63 & Other made-up textile articles; sets; worn clothing, etc. & 59 & 52 & $53 \%$ \\
\hline 64 & Footwear, gaiters and the like; parts of such articles & 61 & 50 & $55 \%$ \\
\hline 65 & Headgear and parts thereof & 57 & 54 & $51 \%$ \\
\hline 66 & Umbrellas, sun umbrellas, walking sticks, seat-sticks, whips, etc. & 49 & 61 & $45 \%$ \\
\hline 67 & Prepared feathers and down and articles made of feathers or of down; etc. & 60 & 51 & $54 \%$ \\
\hline 68 & Articles of stone, plaster, cement, asbestos, mica or similar materials & 42 & 69 & $38 \%$ \\
\hline 69 & Ceramic products & 47 & 64 & $42 \%$ \\
\hline 70 & Glass and glassware & 42 & 69 & $38 \%$ \\
\hline 71 & Natural or cultured pearls, precious or semi-precious stones, etc. & 65 & 45 & $59 \%$ \\
\hline 72 & Iron and steel & 70 & 41 & $63 \%$ \\
\hline 73 & Articles of iron or steel & 72 & 39 & $65 \%$ \\
\hline 74 & Copper and articles thereof & 72 & 39 & $65 \%$ \\
\hline 75 & Nickel and articles thereof & 66 & 45 & $59 \%$ \\
\hline 76 & Aluminium and articles thereof & 68 & 43 & $61 \%$ \\
\hline 78 & Lead and articles thereof & 55 & 55 & $50 \%$ \\
\hline 79 & Zinc and articles thereof & 72 & 38 & $65 \%$ \\
\hline 80 & Tin and articles thereof & 59 & 50 & $54 \%$ \\
\hline 81 & Other base metals; cermets; articles thereof & 59 & 49 & $55 \%$ \\
\hline 82 & Tools, implements, cutlery, spoons and forks, of base metal; etc. & 41 & 70 & $37 \%$ \\
\hline 83 & Miscellaneous articles of base metal & 42 & 69 & $38 \%$ \\
\hline 84 & Machinery, mechanical appliances, nuclear reactors, boilers; parts thereof & 87 & 24 & $78 \%$ \\
\hline 85 & Electrical machinery and equipment and parts thereof; etc. & 84 & 27 & $76 \%$ \\
\hline 86 & Railway or tramway locomotives, rolling stock and parts thereof; etc. & 81 & 30 & $73 \%$ \\
\hline 87 & Vehicles other than railway or tramway rolling stock, and parts etc. & 78 & 33 & $70 \%$ \\
\hline 88 & Aircraft, spacecraft, and parts thereof & 75 & 35 & $68 \%$ \\
\hline 89 & Ships, boats and floating structures & 76 & 34 & $69 \%$ \\
\hline 90 & Optical, photographic, cinematographic, measuring, checking, etc. & 91 & 20 & $82 \%$ \\
\hline 91 & Clocks and watches and parts thereof & 74 & 37 & $67 \%$ \\
\hline 92 & Musical instruments; parts and accessories of such articles & 54 & 57 & $49 \%$ \\
\hline 93 & Arms and ammunition; parts and accessories thereof & 32 & 66 & $33 \%$ \\
\hline 94 & Furniture; bedding, mattresses, mattress supports, cushions etc. & 50 & 61 & $45 \%$ \\
\hline 95 & Toys, games and sports requisites; parts and accessories thereof & 52 & 59 & $47 \%$ \\
\hline 96 & Miscellaneous manufactured articles & 43 & 68 & $39 \%$ \\
\hline 97 & Works of art, collectors' pieces and antiques & 55 & 55 & $50 \%$ \\
\hline Total & & 5,845 & 4,774 & $55 \%$ \\
\hline
\end{tabular}

Note: due to the limited space, the titles of product groups have been cut.

Source: authors' calculation. 
Table 8 shows the results of the sign tests according to the product groups. The product groups with the highest sign matching rates, which are above $80 \%$, are Mineral fuels, mineral oils and products of their distillation; bituminous substances; etc. - code 27 (86\%) and Optical, photographic, cinematographic, measuring, checking, precision, medical or surgical etc. - code 90 (82\%). On the other hand, the product groups with the lowest sign matching rates, which are below 35\%, are Rubber and articles thereof - code $40(32 \%)$, Impregnated, coated, covered or laminated textile fabrics; textile articles of a kind suitable etc. - code 59 (32\%), Arms and ammunition; parts and accessories thereof - code 93 (33\%), Knitted or crocheted fabrics - code 60 (33\%), Printed books, newspapers, pictures and other products of the printing industry; manuscripts - code $49(33 \%)$ and Wool, fine or coarse animal hair; horsehair yarn and woven fabric - code $51(34 \%)$.

In Figure 2 the percentages of matched signs according to geographical region of a country are shown. The most successful matched signs rate was achieved in countries from the Middle East and North Africa (69\%). The key finding is that HOV mainly holds in oil-rich economies. One of the reasons for this could be a focus on exports of only one essential product, oil, but a more detailed analysis should be conducted to validate this result. On the other hand, only countries from Sub-Saharan Africa achieved the percentage of matched signs below $50 \%$.

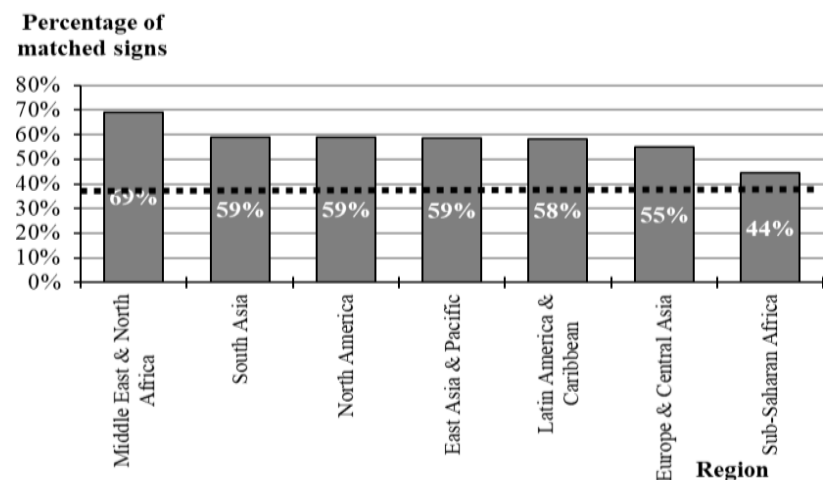

Fig. 2 Percentage of matched signs according to geographical region of a country, $n=111$ observed countries, data for 2014

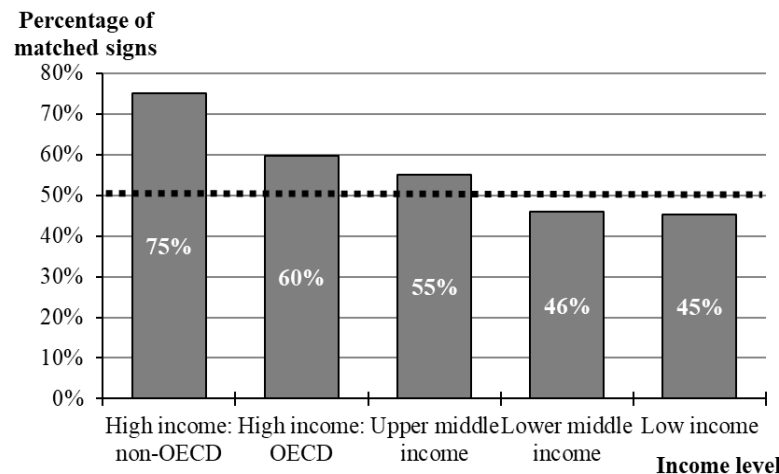

Fig. 3 Percentage of matched signs according to income level of countries, $n=111$ observed countries, data for 2014 
The successfulness of signs matching was observed according to the country income level as well. Figure 3 shows that the highest percentage of matched signs is achieved for countries having high income and which are not members of the Organisation for Economic Cooperation and Development (OECD). Countries with lower middle income $(46 \%)$ and low income (45\%) achieved lower percentage of matched signs in comparison to the benchmark value of $50 \%$. It could be asked: why do rich countries have higher matching rates than poor countries? The reason could be more efficient use of country's comparative advantages and the specialization in production and export.

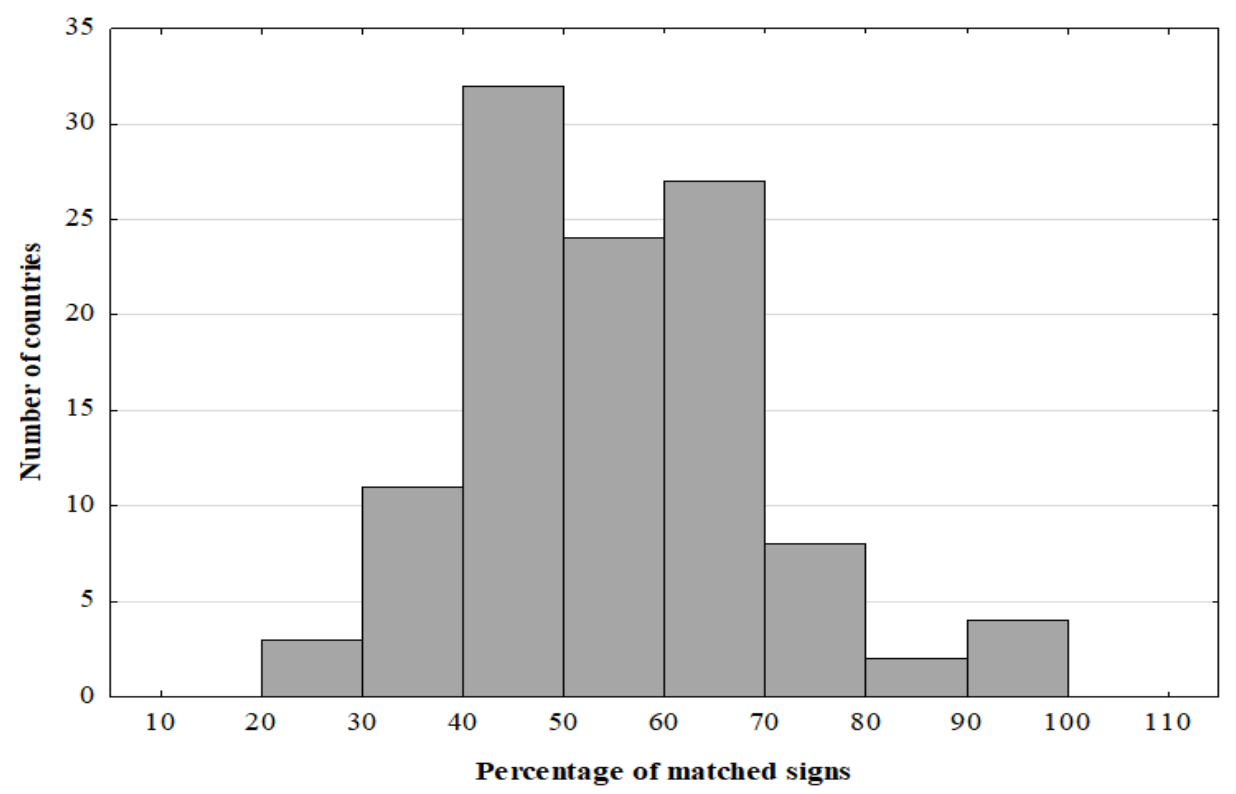

Fig. 4 Histogram of distribution of matched signs, n=111 observed countries, data for 2014

Finally, in Figure 4 the histogram of distribution of matched signs across countries is shown. It turned out that most countries (32) have a percentage of matched signs between $40 \%$ and $50 \%$. It has to be emphasized that three countries, out of thirty-two, have a percentage of matched signs that equals $50 \%$. However, 68 countries or $61 \%$ of observed countries have a percentage of matched signs above the benchmark value of $50 \%$.

Previous empirical tests mainly failed to prove HOV theorem, or did so only in a certain extent, which provides ground for further (amended) tests. We should keep in mind that completely random pattern of signs, such as obtained by flipping a coin, would still generate correct signs $50 \%$ of the time in a large sample. Overall result of the sign test conducted in this paper is only $55 \%$ of matched signs, which is not enough to present it as a proof of HOV theorem validity. Therefore, the sign test must do considerably better in order to be concluded that the HOV theorem is empirically sound. The advantage of this approach is that it allows for the larger sample of countries to be included in the analysis. Disadvantage of this approach is that it assumes the identical technology in countries despite the inclusion of the $R \& D$ variable. Also gross value of trade flows does not reveal country's value added comprised in these flows. For example, China's huge exports of hi- 
tech electronics do not represent its net exports of capital intensive and R\&D intensive products, because its value added in this sector is different from value added upward in the global value chain.

\section{CONCLUSIONS}

This paper introduces new approach for testing the Heckscher-Ohlin-Vanek theorem. The HOV theorem was tested in the case of 111 countries worldwide. Instead of calculating the factor content requirements based on the input-output tables, the normalized trade balance was calculated. The products or goods are divided into five groups according to their production intensity (labour-intensive goods, capital intensive goods, natural-resources intensive goods, easy-to-imitate technology intensive goods and hard-to-imitate technology intensive goods). Furthermore, the countries' factors of production are divided into produced capital, labour force and natural resources further divided into six factors. The sign test inspected correct matching signs between normalized trade balance indices and factor endowments for each country and product according to the SITC 2 classification of products. Overall sign matching rate turned out to be $55 \%(5,845$ matched signs and 4,774 unmatched signs). Countries with the highest sign matching rates of above $90 \%$ were Iraq (97\%), Kuwait (93\%), Qatar (92\%) and Oman (92\%). Countries with the lowest sign matching rates, of below 30\% were the Republic of the Congo (24\%), Niger (25\%) and Albania $(28 \%)$. It seems that countries with a higher income level have higher percentage of matched signs (high-income non-OECD and high-income OECD countries with $75 \%$ and $60 \%$ of sign matches respectively). On the other hand, lower-middle income and lowincome countries had a percentage of matched signs below 50\%. The fact that the missing values were imputed by using data from other periods should be taken as a limitation of research so the results where the R\&D variable was included in the analysis should be carefully discussed. Further research should be made by using this new approach. Improvement could be made by including productivity differences among countries by calculating the effective factor endowments.

\section{REFERENCES}

Artal-Tur, A., Castillo-Giménez, J., Requena-Silvente, R., \& Llano-Verduras, C. (2008). Extending the Heckscher-Ohlin-Vanek model in a regional setting: the role of intermediates, technological differences and space. http://www.etsg.org/ETSG2009/papers/artal.pdf

Bowen, H. P., Leamer, E. E., \& Svikauskas, L. (1987). Multi-country, Multi-factor Tests of the Factor Abundance Theory. The American Economic Review, 77(5), 791-809.

Chakrabarti, A. (2005). The Heckscher-Ohlin-Vanek Theorem and International Factor Price Differences. Open economies review, 16, 407-412.

Choi, E. K. (2004). The Hescher-Ohlin-Vanek Theorem without Factor Price Equalization. Draft (April 19, 2004). https://pdfs.semanticscholar.org/325c/ad4db297024a046b5b22bd2d93f1e9db4658.pdf

Davis, D. R., Weinstein, D. E., Bradford, S. C., \& Shimpo, K. (1997). Using International and Japanese Regional Data to Determine When the Factor Abundance Theory of Trade Works. The American Economic Review, $87,421-446$.

Davis, D., \& Weinsten, D. (2001). The factor content of trade, Working Paper 8637. http://www.columbia.edu/ $\sim$ dew35/PDF/Hdbk_Empir.pdf

Erlat, G., \& Erlat, H. (2003). Measuring Intra-Industry and Marginal Intra-Industry Trade: The Case for Turkey. Emerging Markets Finance and Trade, 39(6), 5-38.

Feenstra, R. C. (2003). Advanced international trade: Theory and Evidence. Princeton, NJ: Princeton University Press. 
Heckscher, E. F. (1919). The effect of foreign trade on the distribution of income. Ekonomisk Tidskrift, $21,497-$ 512. Reprinted in Ellis, H.S. \& L.A. Metzler, (eds.), Readings in the Theory of International Trade. London: Allen and Undwin.

Jošić, H. (2016). Testing the factor proportions model for Croatia. Ekonomski vjesnik/EconViews, 2017(2), 353-370. Kim, U. Y. (1991). Heckscher-Ohlin-Vanek theory and empirical study. The Korean Economic Review, 7(2), 173-189. Leontief, W. (1953). Domestic Production and Foreign Trade: The American Capital Position Re-Examined. Proceedings of the American Philosophical Society, 97, 332-349.

Lu, M., Milner, C., \& Yu, Z. (2009). Testing the H-O-V Model in Bilateral Trade with Allowance for Technology Differences. European Trade Study Group (ETSG) Annual Conference at the University of Rome "Tor Vergata" (September 10-12, 2009).

Maskus, K. E., \& Nishioka, S. (2006). Development-Related Biases in Factor Productivities and the HOV Model of Trade. Discussion papers in economics, Working Paper No. 06-08.

Maskus, K., E., \& Webster, A. (1999). Estimating the HOV Model with Technology Differences Using Disaggregated Labor Skills for the United States and the United Kingdom. Review of International Economics, 7(1), 8-19.

Nishioka, S. (2005). An Explanation of OECD Factor Trade with Knowledge Capital and the HOV Model. Discussion papers in economics, Working Paper No. 05-06. https://www.colorado.edu/economics/sites/default/files/attachedfiles/wp05-06.pdf

Ohlin, B. (1924). The Theory of Trade. Translated and reprinted in Flam, H., \& Flanders, M. J. (editors and translators), Heckscher-Ohlin Trade Theory. Cambridge: MIT Press.

Requena, F., Castillo, J., \& Artal, A. (2005). Multiregion, multifactor tests of the Heckscher-Ohlin-Vanek using Spanish regional data. XXX Simposio Análisis Económico. Murcia: Servicio de Publicaciones de la Universidad de Murcia, 15-17 Septembre 2005.

Romalis, J. (2004). Factor proportions and the structure of commodity trade. American Economic Review, 94, 67-97.

Srivastava, A. (2012). Heckscher Ohlin Vanek Theorem: an excess supply approach, Munich Personal RePEc Archive. https://ideas.repec.org/p/pra/mprapa/38279.html

Srivastava, A., \& Mathur, S. K. (2014). Validity of Heckscher-Ohlin-Vanek Hypothesis - A Complete and Partial Test Approach. Korea and the World Economy, 15(3), 355-393.

Trade Map (2019). List of products imported and exported by certain country. https://www.trademap.org/Product SelCountry_TS.aspx

Trefler, D. (1995). The Case of the Missing Trade and Other Mysteries. American Economic Review, 1029-1046.

Vanek, J. (1968). The factor proportions theory: The N-factor case. Kyklos, 2, 749-754.

World Bank (2018). The Changing Wealth of Nations 2018: Country Tool. https://development-data-hub-s3official.s3.amazonaws.com/ddhfiles/94641/cwon2018-country-tool-v1.0_0.xlsx

World Bank (2019a). Capture fisheries production (metric tons). https://data.worldbank.org/indicator/ER.FSH. CAPT.MT

World Bank (2019b). GDP (current US\$). https://data.worldbank.org/indicator/NY.GDP.MKTP.CD

World Bank (2019c). Labor force, total. https://data.worldbank.org/indicator/SL.TLF.TOTL.IN

World Bank (2019d). Researchers in R\&D (per million people). https://data.worldbank.org/indicator/ SP.POP.SCIE.RD.P6

Wu, T., Tomassin, P. J., \& Mukhopadhyay, K. (2017). Using H-O-V Theorem to Predict the Factor Intensities in Canadian Agricultural Trade. International Journal of Applied Economics, 14(1), 45-64.

Zimring, A. (2015). Testing the Heckscher-Ohlin-Vanek Theory with a Natural Experiment. Canadian Journal of Economics, 52(1), 58-92.

\section{TESTIRANJE HECKSCHER-OHLIN-VANEKOVOG TEOREMA KORIŠĆENJEM PRISTUPA NORMALIZOVANOG TRGOVINSKOG BILANSA}

Studija opisana ovde uvodi pristup normalizovanog trgovinskog bilansa za testiranje HeckscherOhlin-Vanekovog (HOV) teorema. Namera je bila da se sve zemlje širom sveta uključe u analizu, ali je zbog nedostatka podataka određeni broj zemalja morao da bude isključen iz analize. Zbog toga je ukupno 111 zemalja primećeno prema regionu i nivou prihoda u 2014. Pri proceni HOV modela koristio se test predznaka. Test je uporedio očekivani znak normalizovanog trgovinskog bilansa ili neto izvoza prema klasifikaciji proizvoda SITC 2 sa relativnom zadužbinom proizvodnih faktora koji se intenzivno 
koriste u proizvodnji određenog proizvoda. Proizvodni faktori su podeljeni na grupe kao što su proizvedeni kapital, radna snaga i prirodni resursi koji su dodatno podeljeni na šume, metale i minerale, naftu, ugalj i gas, pašnjake $i$ useve. Varijabla istraživači u $R \& D$ na milion ljudi predstavlja uticaj tehnoloških razlika širom zemalja. Rezultat testa predznaka je pokazao da HOV teorem drži u 55 odsto slučajeva. Procenat podudarnih predznakova je najveći za zemlje sa visokim prihodima koje nisu članice OECD-a (75\%) i najniži za zemlje sa nižim srednjim prihodima i niskim prihodima (ispod 50\%).

Ključne reči: Heckscher-Ohlin-Vanekov model, test predznaka, pristup normalizovanog trgovinskog bilansa, svet 